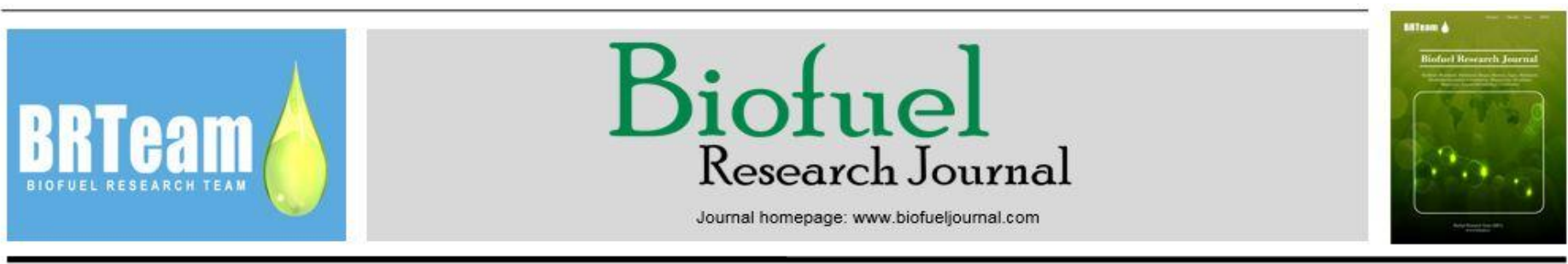

Original Research Paper

\title{
Mass-energy balance analysis for estimation of light energy conversion in an integrated system of biological $\mathrm{H}_{2}$ production
}

\author{
A.I. Gavrisheva ${ }^{1}$, B.F. Belokopytov ${ }^{2}$, V.I. Semina ${ }^{1,3}$, E.S. Shastik ${ }^{1}$, T.V. Laurinavichene ${ }^{1}$, A.A. Tsygankov ${ }^{1, *}$ \\ ${ }^{1}$ Institute of Basic Biological Problems, Russian Academy of Sciences, Pushchino, Moscow Region, 142290, Russia. \\ ${ }^{2}$ Institute of Physiology and Biochemistry of Microorganisms, Russian Academy of Sciences, Pushchino, Moscow Region, 142290, Russia. \\ ${ }^{3}$ LLC "Ecoproject”, Mytishchi, 141014, Moscow Region, Russia.
}

\section{HIGHLIGHTS}

$>$ The conversion of light energy into $\mathrm{H}_{2}$ was examined in an integrated three-stage scheme. $>$ Mass-energy balance regularities were applied to estimate energy conversion efficiencies at different stages. counterproductive for light energy bioconversion to $\mathrm{H}_{2}$.
$>$ This three-stage scheme was found

\section{GRAPHICAL ABSTRACT}

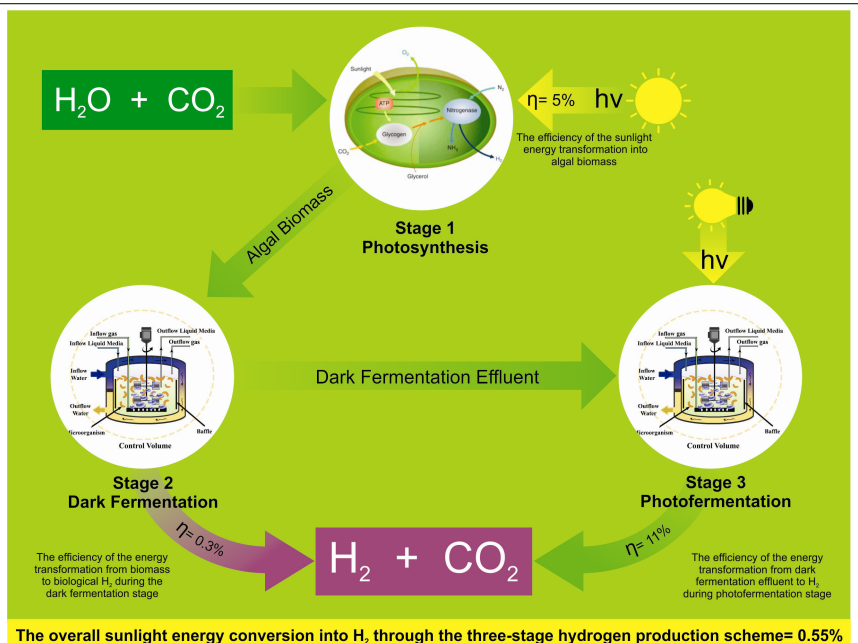

\section{ARTICLE INFO}

\section{Article history:}

Received 27 October 2015

Received in revised form 17 November 2015

Accepted 18 November 2015

Available online 1 December 2015

\section{Keywords:}

Microalgae

Energy conversion efficiency

Hydrogen production

Fermentation

Purple bacteria

Mass-energy balance
The overall sunlight energy conversion into $\mathrm{H}_{2}$ through the three-stage hydrogen production scheme $=0.55 \%$

Corresponding author at: Tel.: +7-4967-731869

E-mail address: ttt-00@mail.ru

Please cite this article as: Gavrisheva A.I., Belokopytov B.F., Semina V.I., Shastik E.S., Laurinavichene T.V., Tsygankov A.A. Mass-energy balance analysis for estimation of light energy conversion in an integrated system of biological $\mathrm{H}_{2}$ production. Biofuel Research Journal 8 (2015) 324-330. DOI: $10.18331 /$ BRJ2015.2.4.7 


\begin{tabular}{|ll|}
\hline Abbreviations & \\
Bchl & Bacteriochlorophyll \\
Chl & Chlorophyll \\
FE & Fermentation effluent \\
DW & Dry weight \\
HS & High salt \\
PhBR & Photobioreactor \\
TAP & Tris-Acetate-Phosphate \\
\hline
\end{tabular}

\section{Introduction}

Our dependence on fossil fuels correlates with the increasing level of carbon dioxide concentration in the atmosphere. To avoid this problem, new alternative energy sources should be introduced into the practice.

Microalgae are unicellular organisms capable of converting light into chemical energy. They grow faster than plants and do not compete with plants for the land. That is why microalgal biomass is considered as a valuable alternative energy source. Different approaches of microalgal biomass usage as an energy source are under investigations including direct digestion into methane (González-Fernández et al., 2012), biodiesel (Sheehan et al., 1998; Verma et al., 2010) and ethanol (Miranda et al., 2012). Complex utilization of microalgal biomass is also being pursued (Rizwan et al., 2015).

Another possibility of microalgal biomass usage is a three-stage integrated system for $\mathrm{H}_{2}$ production in which the first stage is microalgal biomass production followed by the dark fermentation of the algal biomass as the second stage, and finally the photofermentation of the dark fermentation products (Fig. 1).

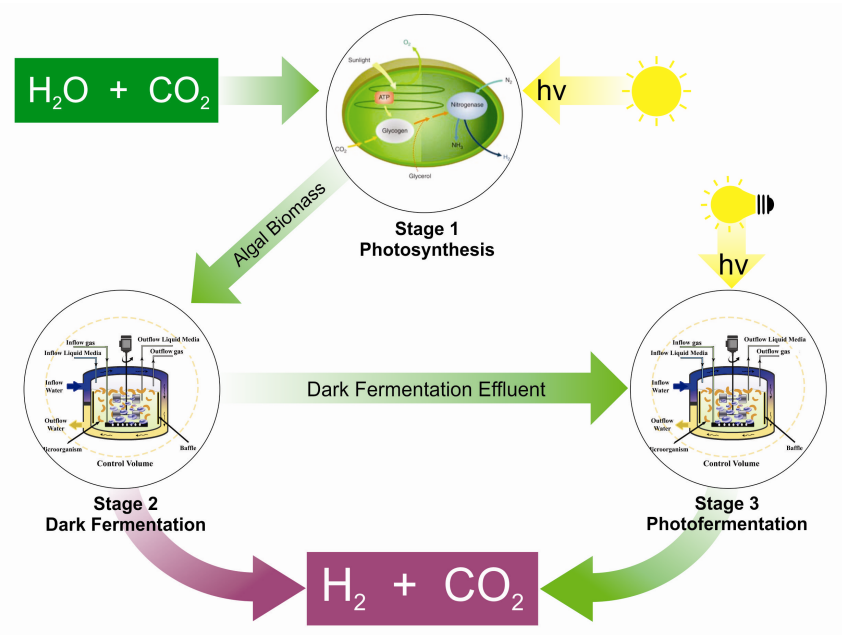

Fig.1. An integrated scheme for the light energy accumulation by microalgae, dark fermentation of algae biomass and photofermentation of the dark fermentation effluent.

This three-stage $\mathrm{H}_{2}$ production has been studied by several research teams (Ike et al., 1998; Ike et al., 2001; Kim et al., 2006). The dark fermentation of microalgae biomass with $\mathrm{H}_{2}$ production has been most successful if biomass is rich in starch. Kim et al. (2006) claimed that the highest $\mathrm{H}_{2}$ yield achieved at this stage was $2.58 \mathrm{~mol} \mathrm{~mol}^{-1}$ glucose, calculated on the basis of accumulated starch. They also reported that during the photofermentation of the dark fermentation effluent (FE), the $\mathrm{H}_{2}$ yield increased to $5.7 \mathrm{~mol} \mathrm{~mol}^{-1}$ glucose, and the total $\mathrm{H}_{2}$ yield amounted to $8.3 \mathrm{~mol} \mathrm{~mol}^{-1}$ glucose (Kim et al., 2006). However, it is worth noting that by taking into account the fact that microalgal biomass contains other organics besides starch, the $\mathrm{H}_{2}$ yields may be over-estimated.

In a different study, Kawaguchi et al. (2001) argued that they successfully produced hydrogen from the starch fraction of the biomass using the mixed culture of Lactobacillus amylovorus and Rhodobium marinum A-501. In their proposed system, L. amylovorus, which possesses amylase activity, utilized algal starch for lactic acid production, and $R$. marinum A-501 produced hydrogen in the presence of light using lactic acid as an electron donor. In the described experiments, the biomass of Dunaliella and Chlamydomonas was freezed-thawed (Kawaguchi et al., 2001). This procedure disrupts most of the cells, simplifying biomass processing in the dark fermentation reactor. In some cases, the processing of microalgal biomass was not described. Though these results are promising in terms of high $\mathrm{H}_{2}$ yield and with respect to algal starch, but the efficiency of the light energy transformation in the system was not considered. In better words, the particular elements of these systems have been explored thoroughly but there is no estimation of the total efficiency of the system, i.e., the ratio of the energy of the $\mathrm{H}_{2}$ obtained to the energy of the incident light. It is worth mentioning that these systems theoretically require only sunlight and are neutral in terms of $\mathrm{CO}_{2}$ production and are therefore, considered very promising.

On such basis, the aim of the present work was to realize the three-step integrated system for $\mathrm{H}_{2}$ production using microalgae, dark fermentative, and purple bacteria, and to estimate the overall efficiency of energy conversion using mass-energy balance regularities.

\section{Materials and methods}

\subsection{Microalgae and purple bacteria}

Stock cultures of Chlamydomonas reinhardtii, strain Dang cc124, and Chlorella pyrenoidosa $82 T$ were maintained on agar plates with a standard Tris-Acetate-Phosphate (TAP) medium (pH 6.9) at $28{ }^{\circ} \mathrm{C}$ under illumination $\left(36 \mu \mathrm{E} \mathrm{m}^{-2} \mathrm{~s}^{-1}\right)$. Single colonies were transferred into $10 \mathrm{ml}$ of TAP medium and incubated for $2 \mathrm{~d}$ under the same conditions. Then, the cultures were grown autotrophycally on the High-Salt (HS) medium (Sueoka et al., 1967) in $500 \mathrm{ml}$ Erlenmeyer flasks which were bubbled with $2 \% \mathrm{CO}_{2}$ in air, filtered through $0.2 \mathrm{~mm}$ pore-size membrane filters (Acro $37 \mathrm{TF}$, Gelman Sciences, Inc., Ann Arbor, $\mathrm{MI}$ ). The $\mathrm{CO}_{2}$ content in the airflow was analyzed with a DX6100-01 gas analyzer (RMT Ltd., Russia) and maintained using a TRM1 microprocessor system (Oven, Russia).

A microbial consortium (with Clostridia predominated) obtained from silo pit liquid (Belokopytov et al., 2009) was used during the dark fermentation stage. The inoculum was grown anaerobically using the medium recommended for biogas-producing microbial communities (Tzavkelova et al., 2012), and was then adapted for starch hydrolysis at 37 ${ }^{\circ} \mathrm{C}$ (Belokopytov et al., 2009).

The purple bacterium Rhodobacter sphaeroides N7 (Khusnutdinova et al., 2012) was used at the photofermentative stage. The inoculum was grown 4-5 d on the Ormerod medium (Ormerod et al., 1961) with $10 \mathrm{mM}$ $\left(\mathrm{NH}_{4}\right)_{2} \mathrm{SO}_{4}$ and $20 \mathrm{mM}$ lactate at $28^{\circ} \mathrm{C}, 60 \mathrm{~W} \mathrm{~m}{ }^{-2}$.

\subsection{Microalgae cultivation}

To study the efficiency of light energy conversion and to produce microalgae biomass, $C$. reinhardtii was cultivated on the HS medium in a $1.5 \mathrm{~L}$ photobioreactor $(\mathrm{PhBR})$ consisting of glass coaxial cylinders (Tsygankov et al., 1994). The thickness of the culture layer was $13 \mathrm{~mm}$. The computerized system was designed to maintain the turbidostat mode (OD $0.05, \mathrm{pH} 7.0$, and $28.0 \pm 0.2{ }^{\circ} \mathrm{C}$ ). The inoculum was added at $5-10 \%$. The culture was bubbled with $3 \% \mathrm{CO}_{2}$ in air at $137 \mathrm{ml} \mathrm{min}^{-1}$. The PhBR was illuminated with cool-white fluorescent lamps with the light intensity varying from 36.7 to $256.6 \mu \mathrm{E} \mathrm{m}^{-2} \mathrm{~s}^{-1} \mathrm{PAR}$. The illuminated area of the culture was $0.083 \mathrm{~m}^{2}$. The outflow culture was collected in $10 \mathrm{~L}$ vessels during $7 \mathrm{~d}$. Then, the biomass was harvested by centrifugation (4500 rpm, $15 \mathrm{~min}$ ) and stored at $-10{ }^{\circ} \mathrm{C}$. The microalgae Chl. pyrenoidosa was grown in a similar manner in the same medium.

\subsection{Hydrolysis of C. reinhardtii biomass}

Our preliminary experiments showed that microbial consortium from silo pit liquid did not digest intact cells of $C$. reinhardtii even during 1 month. That is why the pretreatment of biomass appeared to be necessary. The biomass of C. reinhardtii was hydrolyzed as follows: $187.5 \mathrm{~g}$ of the 
thawed biomass (corresponding to $15 \mathrm{~g}$ of dry weight, $\mathrm{DW}_{\text {C.r. }}$ ) was incubated in $112.5 \mathrm{~mL}$ of $3.5 \mathrm{~N} \mathrm{H}_{2} \mathrm{SO}_{4}$ at $120{ }^{\circ} \mathrm{C}, 1.2 \mathrm{~atm}, 30 \mathrm{~min}$.

\subsection{Anaerobic dark fermentation of microalgae biomass}

Before fermentation, the $\mathrm{pH}$ of the hydrolysate was adjusted to 6.8 . Moreover, the hydrolysate was supplied with $\mathrm{Mg}, \mathrm{Ca}$, microelements, and phosphates according to the medium composition described by Tzavkelova et al. (2012). Fermentation was performed anaerobically at $37^{\circ} \mathrm{C}$ in $500 \mathrm{~mL}$ vessels using $4 \mathrm{~mL}$ of the microbial consortium as inoculum. At the end of the fermentation, the culture $(450 \mathrm{~mL})$ was neutralized to $\mathrm{pH} 7.0$ and harvested by centrifugation ( $4500 \mathrm{rpm}, 15 \mathrm{~min}$ ). The supernatant was autoclaved, centrifuged again, and was used as fermentation effluent (FE)

\subsection{Utilization of FE for cultivation of purple bacteria (photofermentation)}

To cultivate the purple bacteria, i.e., $R$. sphaeroides N7, the FE was used in non-diluted or diluted form with distilled water, as specified. When indicated some nutrients were added (mg L$\left.{ }^{-1}\right)$ : YE, 100; $\mathrm{FeSO}_{4} .7 \mathrm{H}_{2} \mathrm{O}, 10$; EDTA, 20. Experiments were made in Hungate tubes $(16 \mathrm{~mL})$ with $8 \mathrm{~mL}$ of the medium with $2 \%$ of inoculum, under Ar. Tubes were incubated at $28{ }^{\circ} \mathrm{C}$ under illumination; $60 \mathrm{~W} \mathrm{~m}^{-2}$ (incandescent lamps).

\subsection{Other methods}

Chlorophyll (Chl) $a+b$ content was assayed spectrophotometrically in $95 \%$ ethanol extract (Harris, 1989). Bacteriochlorophyll (Bchl) $a$ concentration was measured spectrophotometrically at $772 \mathrm{~nm}$ after extraction in 7:2 (v/v) acetone:methanol (Clayton, 1966). Gas production was measured manometrically, and the $\mathrm{H}_{2}$ percentage was analyzed by gas chromatography. The concentration of acetate was determined by gas chromatography as described earlier (Belokopytov et al., 2009). Lactate concentration was assayed by enzymatic method and monitored as NAD reduction at $340 \mathrm{~nm}$ (Asatiani, 1969). Glucose concentration was measured by using the Glucose GOD FS kit (DiaSys, Germany). Starch accumulated in the cells was determined as glucose (see above) after enzymatic hydrolysis, according to the method described by Gfeller and Gibbs (1984). The total content of soluble monosacharides and polysaccharides (which could be hydrolyzed by sulfuric acid) was assayed using anthrone reagent and expressed as glucose equivalents (Hanson and Phillips, 1984). Protein concentration was estimated according to the classical Lowry method. The ammonium content was analyzed by the microdiffusion method (Lyubimov et al., 1968). Light intensity was measured in the 400-900 $\mathrm{nm}$ region using quantometer (Quantum Meter QMSW-SS) and pyranometer (CM3; Kipp\&Zonen, Delft, The Netherlands). During measurements, infrared light with a wavelength more than $850 \mathrm{~nm}$ was cut off by filter SZS24. Carbon, hydrogen, and nitrogen $(\mathrm{CHN})$ content in biomass was measured using a $\mathrm{CHN}$ analyzer.

\section{Calculations of energetic efficiency}

Calculations were made using the mass and energy balance regularities (Erickson et al., 1978). The energy content of dry algae biomass $\left(Q_{b}\right)$ was calculated using the Equation 1:

$\mathrm{Q}_{\mathrm{b}}\left(\mathrm{kJ} \mathrm{g}^{-1}\right)=112.8 \times \gamma / \mathrm{M}_{\mathrm{b}}$

where 112.8 is the heat released during the combustion of biomass, which contains $1 \mathrm{~g}$-atom of carbon, with the degree of reduction $\gamma . \mathrm{M}_{\mathrm{b}}$ is the calculated molecular mass of biomass, equal to 25.564 and $25.532 \mathrm{~g} \mathrm{~mol}^{-1}$ for C. reinhardtii and Chl. pyrenoidosa, correspondingly. The biomass elemental composition is given below.

To calculate $\gamma$, the CHN content was measured. The $\mathrm{O}$ content was calculated assuming that biomass contains $95 \%$ CHNO. According to our measurements, the empirical elemental composition of $C$. reinhardtii and Chl. pyrenoidosa was $\mathrm{CH}_{0.128} \mathrm{~N}_{0.178} \mathrm{O}_{0.684}$ and $\mathrm{CH}_{0.132} \mathrm{~N}_{0.192} \mathrm{O}_{0.666}$, correspondingly. The biomass degree of reduction $(\gamma)$ was calculated based on the Equation 2:

$\gamma=4+x+3 y-2 z$ where $\mathrm{x}, \mathrm{y}, \mathrm{z}$ represent the numbers of $\mathrm{H}, \mathrm{N}, \mathrm{O}$ atoms, correspondingly, based on biomass composition. Consequently, $\gamma$ is 3.294 and 3.376, and energy content of biomass is 14.5 and $14.9 \mathrm{~kJ} \mathrm{~g}^{-1}$ for $C$. reinhardtii and Chl. pyrenoidosa, respectively.

The efficiency of light energy conversion to energy accumulated in biomass ( $\mathrm{y}$ ) was calculated as shown in the Equation 3:

$\mathrm{y}(\%)=100 \mathrm{E}_{\mathrm{b}} / \mathrm{E}_{\mathrm{il}}$

where $E_{b}$ is the energy of heat combustion of biomass produced by the $\mathrm{PhBR}$ during $1 \mathrm{~h}, \mathrm{E}_{\mathrm{il}}$ is the incident light energy to the PhBR during $1 \mathrm{~h}$.

The energy of heat combustion of biomass produced by the PhBR during $1 \mathrm{~h}\left(\mathrm{E}_{\mathrm{b}}\right)$ was calculated as follows (Eq. 4):

$\mathrm{E}_{\mathrm{b}}\left(\mathrm{kJ} \mathrm{h}^{-1}\right)=112.8 \times \mu \times \mathrm{C} \times \gamma \times \mathrm{V}$

where $\mu$ is specific growth rate $\left(\mathrm{h}^{-1}\right), \mathrm{C}$ is the steady-state biomass concentration in the PhBR measured as the number of moles of carbon in biomass per $1 \mathrm{~L}$ of culture $\left(\mathrm{mol} \mathrm{L}^{-1}\right), \mathrm{V}$ is the volume of the culture and is equal to 1.125 and $1.5 \mathrm{~L}$ for $C$. reinhardtii and Chl. pyrenoidosa, correspondingly.

The incident light energy per $1 \mathrm{~h}$ was calculated as follows (Eq. 5):

$\mathrm{E}_{\mathrm{il}}\left(\mathrm{kJ} \mathrm{h}^{-1}\right)=3600 \times \mathrm{I}_{\mathrm{o}} \times \mathrm{S} / 1000$

where $\mathrm{I}_{0}\left(\mathrm{~W} \mathrm{~m}^{-2}\right)$ is the incident light intensity, $\mathrm{S}\left(\mathrm{m}^{2}\right)$ is the illuminated surface of the culture equaling 0.083 and $0.095 \mathrm{~m}^{2}$ for $C$. reinhardtii and Chl. pyrenoidosa, respectively.

The specific energy of substrate combustion $\left(Q_{s}\right)$ was calculated for acetate, lactate, and glucose based on their $\mathrm{CHO}$ formula:

$\mathrm{Q}_{\mathrm{s}}\left(\mathrm{kJ} \mathrm{g}^{-1}\right)=112.8 \times \gamma / \mathrm{M}_{\mathrm{s}}$

where $\gamma$ is 4 and $\mathrm{M}_{\mathrm{s}}$ is 30 (formula of a common type $\mathrm{CH}_{2} \mathrm{O}$ ). Thus, the specific energy of acetate, lactate, and glucose was similar and amounted to $15.04 \mathrm{~kJ} \mathrm{~g}^{-1}$.

The specific energy of hydrogen combustion is $143.1 \mathrm{~kJ} \mathrm{~g}^{-1}$.

\section{Results and discussion}

4.1. Production of microalgae biomass and efficiency of light energy conversion

Production of microalgae biomass was studied using $C$. reinhardtii and Chl. pyrenoidosa under turbidostat cultivation. The growth rate of $C$. reinhardtii increased with the increase of the light intensity and saturated at $38.5 \mathrm{~W} \mathrm{~m}^{-2}$ reaching the maximal value of $0.115 \mathrm{~h}^{-1}$ (Table 1 ).

Table 1.

Influence of incident light intensity on the growth parameters and efficiency of light energy conversion in C. reinhardtii.

\begin{tabular}{|c|c|c|c|c|c|c|}
\hline \multirow[t]{2}{*}{$\begin{array}{c}\mathbf{I}_{\mathbf{0}} \\
\left(\mathbf{W} \mathbf{m}^{-2}\right)^{*}\end{array}$} & \multirow[t]{2}{*}{$\begin{array}{c}\mathbf{E}_{\mathrm{il}} \\
\left(\mathbf{k J ~ \mathbf { h } ^ { - 1 } )}\right.\end{array}$} & \multirow[t]{2}{*}{$\begin{array}{l}\text { Growth } \\
\text { rate, } \mu\left(h^{-1}\right)\end{array}$} & \multicolumn{2}{|c|}{$\begin{array}{l}\text { Biomass concentration } \\
\left(\mathrm{DW}_{\text {C.r. }}\right)\end{array}$} & \multirow[t]{2}{*}{$\begin{array}{c}\mathbf{E}_{\mathrm{b}} \\
\left(\mathbf{k J ~ h}^{-1}\right)\end{array}$} & \multirow[t]{2}{*}{$\begin{array}{c}\mathbf{y} \\
(\%)\end{array}$} \\
\hline & & & $\mathrm{g} \mathrm{L}^{-1}$ & $\mathrm{~mol} \mathrm{~L}^{-1}$ & & \\
\hline 9.7 & 2.9 & 0.011 & 0.22 & 0.009 & 0.04 & 1.4 \\
\hline 14.1 & 4.2 & 0.046 & 0.27 & 0.011 & 0.20 & 4.8 \\
\hline 18.7 & 5.6 & 0.057 & 0.27 & 0.011 & 0.26 & 4.6 \\
\hline 29.5 & 8.8 & 0.079 & 0.24 & 0.009 & 0.30 & 3.4 \\
\hline 38.5 & 11.5 & 0.110 & 0.24 & 0.009 & 0.41 & 3.6 \\
\hline 64.1 & 19.2 & 0.115 & 0.27 & 0.011 & 0.53 & 2.8 \\
\hline
\end{tabular}


The steady-state biomass concentration was about $0.25 \pm 0.02 \mathrm{~g} \mathrm{~L}^{-1}$. Similarly, the energy of heat combustion of biomass produced by the PhBR during $1 \mathrm{~h}\left(\mathrm{E}_{\mathrm{b}}\right)$ (Section 3, Eq. 4) increased with light intensity up to $0.49 \mathrm{~kJ}$ $\mathrm{h}^{-1}$. The incident light energy per $1 \mathrm{~h}\left(\mathrm{E}_{\mathrm{il}}\right)$ increased in proportion to incident light intensity (Section 3, Eq. 5). However, the efficiency of light energy conversion to energy accumulated in biomass ( $\mathrm{n}$; Section 3, Eq. 3) was maximal $(4.8-4.6 \%)$ at rather low light intensities of $14.1-18.7 \mathrm{~W} \mathrm{~m}^{-2}$.

Thus, the optimal conditions for the growth rate (and biomass production) distinctly differed from those for efficiency of the light energy conversion. The most efficient light energy conversion took place when the growth rate was only $40 \%$ of the maximum value.

Similar results were obtained using the turbidostat culture of Chl. pyrenoidosa, while somewhat higher biomass concentration and lower growth rate were obtained (Table 2). The highest light energy conversion efficiency of $5.5 \%$ was observed at low light intensity $\left(18.7 \mathrm{~W} \mathrm{~m}^{-2}\right)$ when the growth rate was $58 \%$ of the maximum value. Since the regularities were the same, $C$. reinhardtii was used in the subsequent experiments.

Table 2.

Influence of incident light intensity on the growth parameters and efficiency of light energy conversion in Chl. pyrenoidosa.

\begin{tabular}{|c|c|c|c|c|c|c|}
\hline \multirow[t]{2}{*}{$\mathbf{I}_{0}\left(W \mathbf{m}^{-2}\right)$} & \multirow{2}{*}{$\begin{array}{c}\mathbf{E}_{\text {il }} \\
\left(\mathbf{k J} \mathbf{h}^{-1}\right)\end{array}$} & \multirow{2}{*}{$\begin{array}{c}\text { Growth rate, } \\
\qquad \mu\left(h^{-1}\right)\end{array}$} & \multicolumn{2}{|c|}{$\begin{array}{c}\text { Biomass concentration } \\
\left(\mathrm{DW}_{\text {Chl.pyr. }}\right)\end{array}$} & \multirow{2}{*}{$\begin{array}{c}\mathbf{E}_{\mathrm{b}} \\
\left(\mathbf{k J ~ h} \mathbf{h}^{-1}\right)\end{array}$} & \multirow[t]{2}{*}{$\begin{array}{c}\text { n } \\
(\%)\end{array}$} \\
\hline & & & $\mathrm{g} \mathrm{L}^{-1}$ & $\mathrm{~mol} \mathrm{~L}^{-1}$ & & \\
\hline 9.7 & 3.3 & 0.016 & 0.26 & 0.010 & 0.09 & 2.7 \\
\hline 18.7 & 6.4 & 0.056 & 0.29 & 0.011 & 0.35 & 5.5 \\
\hline 38.5 & 13.2 & 0.093 & 0.28 & 0.011 & 0.58 & 4.4 \\
\hline 64.1 & 21.9 & 0.097 & 0.35 & 0.014 & 0.78 & 3.6 \\
\hline
\end{tabular}

These findings were in agreement with the published data on the efficiency of the light energy conversion of $0.2-5.0 \%$ (Klass, 1998). It should be noted that this parameter was often calculated in relation to the absorbed light energy bearing in mind that non-absorbed (transmitted) light may be further utilized in some other light-dependent processes. However, it should be emphasized that the intensity of transmitted light is much lower as compared to incident light (10-12\% in the present study). Furthermore, transmitted light is diffused light with modified spectral composition, hence, its utilization is counterproductive. Therefore, the energy of the transmitted light was neglected herein and calculations were made based on the incident light energy.

\subsection{Pretreatment of the raw microalgae biomass}

Our preliminary fermentation experiments using raw algae biomass (after freeze-thawing) failed and only insignificant production of methanecontaining gas was observed (data not shown). Therefore, to improve the fermentation and the availability of carbohydrates to the microorganisms some disruption methods were necessary. Various pretreatment methods have been investigated to produce fermentable sugars from algae biomass ranging from simple heating or freezing-thawing to thermo-acidic or thermo-alkaline hydrolysis (Yang et al., 2011; Liu et al., 2012), ultrasonic disintegration (Jeon et al., 2013; Yun et al., 2013), osmotic shock (Lee et al., 2010), enzymatic pretreatment (Choi et al., 2010). Moreover, different combinations of grinding, enzymatic hydrolysis, hydrogenogens domestication, ultrasonication, microwave-assisted acid heating have also been tested (Cheng et al., 2012). In fact, pretreatment methods are chosen depending on the particular properties of a certain microalgae, especially of their cell wall. Efremenko et al. (2012) applied thermo-acidic pretreatment method for various microalgae and achieved extremely different $\mathrm{H}_{2}$ production rates.

In the present study, the thermo-acidic pretreatment method was used (Section 2.3). This resulted in an increase in the total carbohydrates (measured with anthrone) in the supernatant fraction from 44.8 to $229.7 \mathrm{mg} \mathrm{g}$ ${ }^{1} \mathrm{DW}_{\mathrm{C} . \mathrm{r}}$. Glucose concentration (measured with glucose oxidase) also increased from 0.09 to $4.3 \mathrm{mg} \mathrm{g}^{-1} \mathrm{DW}_{\mathrm{C} . \mathrm{r}}$.

\subsection{Dark anaerobic fermentation of microalgae hydrolysate}

The utilization of algae biomass for $\mathrm{H}_{2}$ production by using various microorganisms e.g., C. butyricum (Kim et al., 2006; Liu et al., 2012), immobilized Clostridium acetobutylicum (Efremenko et al., 2012), and anaerobic sewage sludge microflora (Park et al., 2009), through dark fermentation has been reported. For instance, high $\mathrm{H}_{2}$ production of 81-92 $\mathrm{mL} \mathrm{g}^{-1} \mathrm{DW}$ was demonstrated for Arthrospira platensis and Chl. vulgaris ESP6 hydrolysate obtained through ultrasonic-acid or thermo-acidic pretreatment, correspondingly (Cheng et al., 2012; Liu et al., 2012).

The advantages of monocultures and mixed culture (consortia) have also been widely discussed. Application of pure cultures appears to be very useful approach for experimental estimation of $\mathrm{H}_{2}$ production rates and yields as well as organic acids production. However, in practice, pure culture is not applicable due to high cost of waste sterilization and inability to use wide spectrum of organics (Tekucheva and Tsygankov, 2012).

Even though the dark fermentation of different wastes was studied intensively, this process, however, was not considered in the context of overall efficiency of energy conversion. Hence, the dark anaerobic fermentation of $C$. reinhardtii hydrolysate was performed using a Clostridia-predominated consortium as described in Section 2.4. Carbohydrates (glucose) were consumed while acetate $(20 \mathrm{mM})$ and lactate $(35 \mathrm{mM})$ were produced. Gas production started after $24 \mathrm{~d}$ and continued during the $56 \mathrm{~d}$-experiment. The total $\mathrm{H}_{2}$ production amounted to $5.8 \mathrm{mM}$ per $1 \mathrm{~L} \mathrm{FE}$ (Table 3), thus, the $\mathrm{H}_{2}$ yield was as low as $0.15 \mathrm{~mol}$ $\mathrm{mol}^{-1}$ glucose. Evidently, the heterolactic acid fermentation took place, but the low $\mathrm{H}_{2}$ production signified probably that $\mathrm{H}_{2}$ consumers were available in this microbial consortium. Other researchers also reported that low quantities of $\mathrm{H}_{2}$ were produced from Chl. vulgaris and Dunaliella tertiolecta biomass fermented by anaerobic enrichment cultures derived from digester sludge, and that $\mathrm{H}_{2}$ was subsequently consumed (Lakaniemi et al., 2011).

Table 3.

The products of dark anaerobic fermentation of C. reinhardtii hydrolysate.

\begin{tabular}{|c|c|c|c|c|}
\hline \multirow{2}{*}{$\begin{array}{l}\text { Substrate/ } \\
\text { Products }\end{array}$} & \multicolumn{2}{|c|}{$\begin{array}{c}\begin{array}{c}\text { Concentration of substrate/ } \\
\text { products }\end{array} \\
\end{array}$} & \multicolumn{2}{|c|}{ Total energetic value** } \\
\hline & $\begin{array}{l}\text { mmol L of } \\
\text { FE* }^{*}\end{array}$ & $\begin{array}{l}\mathrm{mg} \mathrm{g}^{-1} \text { of } \\
\mathrm{DW}_{\text {C.r. }}\end{array}$ & $\begin{array}{l}\mathbf{k J} \mathbf{g}^{-1} \text { of } \\
\mathbf{D W}_{\text {C.r. }}\end{array}$ & $\begin{array}{c}\text { kJ } 100 \mathrm{~kJ}^{-1} \text { of } \\
\text { biomass }\end{array}$ \\
\hline \multicolumn{5}{|c|}{$\begin{array}{l}\text { Carbohydrates } \\
\text { (glucose): }\end{array}$} \\
\hline Initial & 42.5 & 230.00 & 3.46 & 23.86 \\
\hline Final & 3.1 & 18.00 & 0.27 & 1.86 \\
\hline $\mathrm{H}_{2}$ & 5.8 & 0.34 & 0.05 & 0.34 \\
\hline $\mathrm{CO}_{2}$ & 4.5 & 14.00 & - & - \\
\hline Acetate & 20.0 & 36.00 & 0.54 & 3.72 \\
\hline Lactate & 35.0 & 99.00 & 1.49 & 10.28 \\
\hline Total & - & - & 2.35 & 16.21 \\
\hline
\end{tabular}

* $1 \mathrm{~L}$ of FE corresponded to initial $33.3 \mathrm{~g}$ of $\mathrm{DW}_{\mathrm{C} . \mathrm{r}}$

** The specific energy of substrate combustion is given in Section 3.

The carbon recovery in the products was close to $65.3 \%$, which probably means that some additional fermentation products were not detected in the hydrolysate or, alternatively, a significant part of microbial biomass was not digested.

Energy content of the glucose consumed as well as the content of the dark fermentation products were calculated based on Equation 6 (Section 3 ). The results obtained showed that the energy content in the glucose available in the hydrolysate was $3.46 \mathrm{~kJ} \mathrm{~g}^{-1}$ (Table 3). Furthermore, the energy content of consumed glucose during the fermentation was $3.19 \mathrm{~kJ}$ $\mathrm{g}^{-1}$. On the other hand, the total energy content of all the measured fermentation products (acetate, lactate, hydrogen, and residual glucose) stood at $2.35 \mathrm{~kJ} \mathrm{~g}^{-1}$. Thus, the energy conversion efficiency of the consumed glucose to all of the measured products during the dark fermentation was $68 \%$ (probably underestimated because some products were not measured). While the energy conversion efficiency of the consumed glucose to $\mathrm{H}_{2}$ was only $1.6 \%$. 
Moreover, by taking into consideration the initial energy content of dry algae biomass amounted to $14.5 \mathrm{~kJ} \mathrm{~g}^{-1}$ of DW $\mathrm{DW}_{\text {C.r. }}$ (Section 3, Eqs. 1 and 2), the energy conversion efficiency of the consumed glucose during the dark fermentation into products and $\mathrm{H}_{2}$ was recalculated at 16.2 and $0.3 \%$, respectively.

4.4. Cultivation of purple bacteria using the FE after dark fermentation (photofermentation)

Theoretically, the VFAs available in the FE could be used for photofermentation by purple bacteria and $\mathrm{H}_{2}$ could be produced according to the Equations 7-9:

$\mathrm{C}_{2} \mathrm{H}_{4} \mathrm{O}_{2}+2 \mathrm{H}_{2} \mathrm{O} \rightarrow 4 \mathrm{H}_{2}+2 \mathrm{CO}_{2}$

$\mathrm{C}_{3} \mathrm{H}_{6} \mathrm{O}_{3}+3 \mathrm{H}_{2} \mathrm{O} \rightarrow 6 \mathrm{H}_{2}+3 \mathrm{CO}_{2}$

$\mathrm{C}_{6} \mathrm{H}_{12} \mathrm{O}_{6}+6 \mathrm{H}_{2} \mathrm{O} \rightarrow 12 \mathrm{H}_{2}+6 \mathrm{CO}_{2}$

Thus, using 1 L FE of a known composition (Table 3), one could obtain 40 mmol of hydrogen from acetate, $105 \mathrm{mmol}$ from lactate and $18.6 \mathrm{mmol}$ from glucose, in total $327.2 \mathrm{mmol} \mathrm{H}_{2}$ per $1 \mathrm{~L}$ of FE. Nevertheless, the cultivation of $R$. sphaeroides $\mathrm{N} 7$ on non-diluted and diluted FE (25-50\%) did not result in $\mathrm{H}_{2}$ production (Table 4). This absence was evidently due to the high level of ammonium content $(22.4 \mathrm{mM})$ in the $\mathrm{FE}$, which was detrimental to the nitrogenase-mediating $\mathrm{H}_{2}$ photoproduction. In fact, this is a common problem for photofermentation stage when using FEs or different wastes with inappropriate $\mathrm{C} / \mathrm{N}$ ratios. Different ways have been suggested to overcome this problem including chemical methods of ammonium removal (Cheng et al., 2012) and application of ammonium insensitive mutants (Heiniger et al., 2012; Ryu et al., 2014).

Table 4.

Final characteristics of $R$. sphaeroides N7 culture grown on the FE (diluted with distilled water) after the dark fermentation.

\begin{tabular}{lccccccc}
\hline $\mathrm{FE}$ & $\begin{array}{c}\text { Bchl, } \\
\left(\mathrm{mg} \mathrm{L}^{-1}\right)\end{array}$ & $\begin{array}{c}\text { Protein } \\
\left(\mathrm{mg} \mathrm{mL}^{-1}\right)\end{array}$ & $\begin{array}{c}\mathrm{NH}_{4}{ }^{+} \\
(\mathrm{mM})\end{array}$ & $\begin{array}{c}\text { Lactate } \\
(\mathrm{mM})\end{array}$ & $\begin{array}{c}\text { Acetate } \\
(\mathrm{mM})\end{array}$ & $\begin{array}{c}\text { Glucose } \\
(\mathrm{mM})\end{array}$ & $\mathrm{H}_{2}$ \\
\hline $50 \%$ & $61.0 \pm 1.4$ & $2.1 \pm 0.1$ & $14.1 \pm 1.2$ & $3.0 \pm 0.3$ & 0 & $1.9 \pm 0.04$ & 0 \\
$50 \% *$ & $66.0 \pm 2.7$ & $1.9 \pm 0.2$ & $16.9 \pm 1.4$ & $2.4 \pm 0.2$ & 0 & $2.8 \pm 0.50$ & 0 \\
\hline
\end{tabular}

* In this case, $\mathrm{YE}, \mathrm{FeSO}_{4} \cdot 7 \mathrm{H}_{2} \mathrm{O}$, and EDTA were added (Section 2.5).

The results obtained by using $R$. sphaeroides $\mathrm{N} 7$ cultivation on $50 \% \mathrm{FE}$ are presented in Table 4. No significant differences were observed in response to dilution of the FE with distilled water or to the addition of some nutrients. It should be noted that the consumption of acetate was about $100 \%$ and that of lactate was above $80 \%$, while the low glucose content did not change. The final concentration of bacterial cells (Bchl)

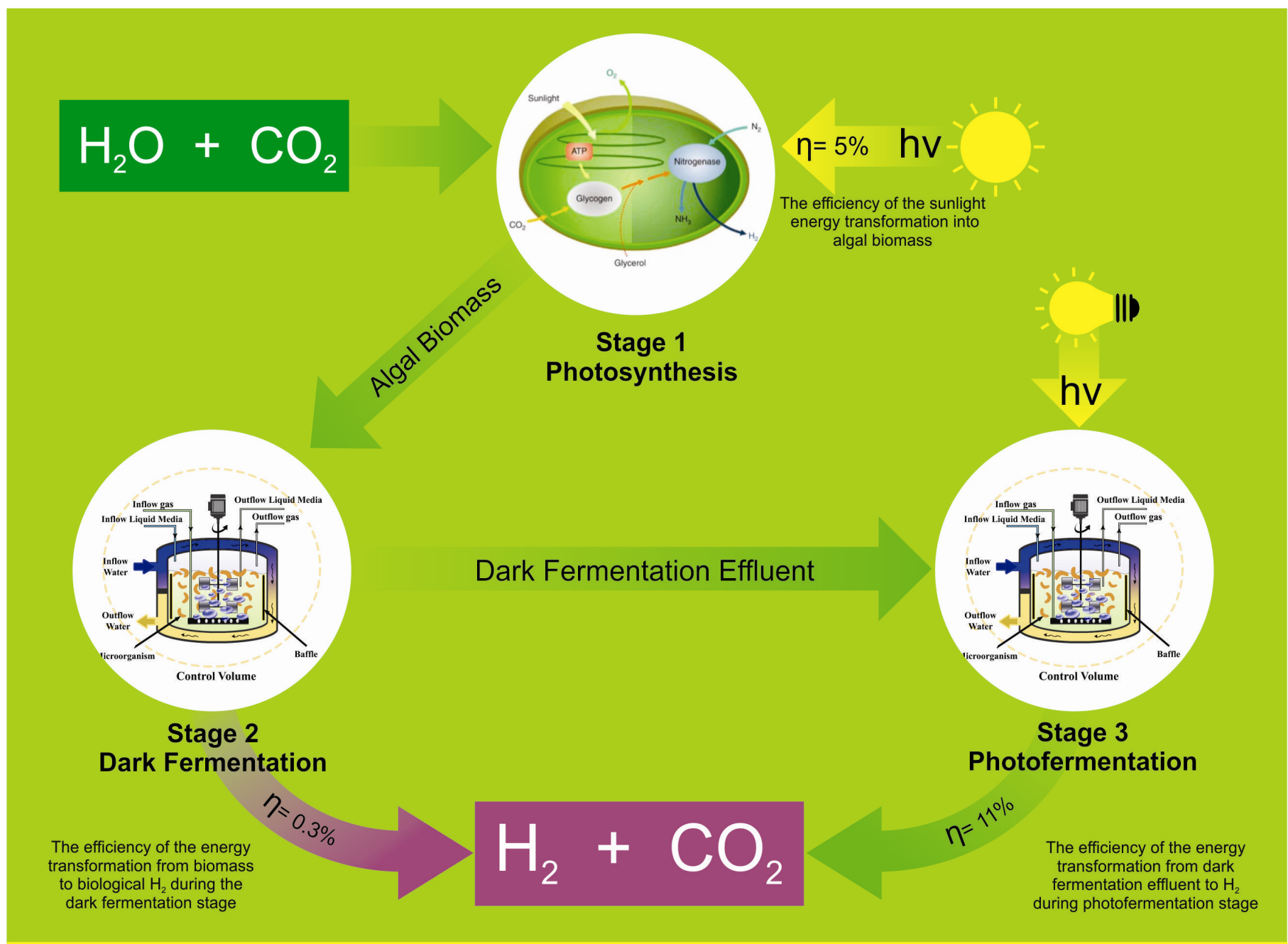

The overall sunlight energy conversion into $\mathrm{H}_{2}$ through the three-stage hydrogen production scheme= $0.55 \%$

Fig.2. The counter-productiveness of the three-stage hydrogen production scheme.

Please cite this article as: Gavrisheva A.I., Belokopytov B.F., Semina V.I., Shastik E.S., Laurinavichene T.V., Tsygankov A.A. Mass-energy balance analysis for estimation of light energy conversion in an integrated system of biological $\mathrm{H}_{2}$ production. Biofuel Research Journal 8 (2015) $324-330$.

DOI: $10.18331 / \mathrm{BRJ} 2015.2 .4 .7$ 
was rather high. Thus, it could be concluded that the medium used was suitable for the growth of the purple bacteria even though the $\mathrm{H}_{2}$ production did not occur.

Nevertheless, to estimate the potential $\mathrm{H}_{2}$ production from the substrates available in the FE (Table 3) at non-inhibiting ammonium concentration, the synthetic $50 \%$ FE was used where the acetate and lactate concentration were identical to those in the $50 \% \mathrm{FE}$ but the ammonium content was limited to 3.3 $\mathrm{mM}$. In this case, $187.6 \mathrm{mmol} \mathrm{H}_{2}$ per $1 \mathrm{~L} \mathrm{FE}$, i.e., $51.5 \%$ of theoretical value was obtained. In another word, the overall $\mathrm{H}_{2}$ production stood at $142.3 \mathrm{~mL} \mathrm{~g}$ ${ }^{1} \mathrm{DW}$ (i.e., $138 \mathrm{~mL} \mathrm{~g}^{-1} \mathrm{DW}$ during the photofermentation and $4.3 \mathrm{~mL} \mathrm{~g}^{-1} \mathrm{DW}$ during the dark fermentation stage).

The energy of the produced hydrogen was estimated as $1.6 \mathrm{~kJ} \mathrm{~g}^{-1} \mathrm{DW}_{\mathrm{C} . \mathrm{r}}$. The energy content of the algae biomass was $14.5 \mathrm{~kJ} \mathrm{~g}^{-1} \mathrm{DW}_{\text {C.r. }}$ (Section 3). Thus, the energy conversion efficiency of the algae biomass to hydrogen was approximately $11 \%$. As demonstrated in Section 4.1 , the efficiency of the light energy conversion into the energy of algae biomass was about $5 \%$. This indicates that the overall efficiency of the light energy conversion to the $\mathrm{H}_{2}$ energy (through biomass synthesis and fermentation stages) was not more than $0.55 \%$ (Fig. 2). Moreover, it should be mentioned that we did not take into account all the additional energy expenditures at various stages (even the light energy consumed by the purple bacteria), which would decrease the efficiency dramatically.

To estimate the potential efficiency of the light energy conversion into $\mathrm{H}_{2}$ using a three-stage scheme, the results obtained in the present study concerning the $1^{\text {st }}$ stage, i.e., microalgae biomass production, could be combined with the most promising results reported previously on the subsequent stages, i.e., dark fermentation and photofermentation. On such basis, the maximal $\mathrm{H}_{2}$ yield reported during dark fermentation and photofermentation was as high as $337 \mathrm{~mL} \mathrm{~g}^{-1} \mathrm{DW}_{A r}$ using Arthrospira biomass (Cheng et al., 2012). In their study, the Arthrospira biomass was treated by microwave-assisted acid heating, enzymatic hydrolysis, and zeolite to remove ammonium (energy expenditure equivalent of $3.9 \mathrm{~kJ} \mathrm{~g}^{-1} \mathrm{DW}_{A r}$ ). Assuming that the energy content of Arthrospira and C. reinhardtii biomass was the same, i.e., $14.5 \mathrm{~kJ} \mathrm{~g}^{-1}$ and that the efficiency of light energy conversion into the energy of algae biomass was about $5 \%$, the efficiency of biomass energy conversion into $\mathrm{H}_{2}$ energy will be $27 \%$ and the total energy conversion efficiency of initial light energy into the $\mathrm{H}_{2}$ energy will not exceed $1.4 \%$. Admittedly, the input of the light energy during the $3^{\text {rd }}$ stage was not taken into account, and therefore, the accurate results will be much lower.

\section{Conclusions}

The application of mass and energy balance regularities appeared to be useful for the estimation of the efficiency of light energy conversion into the hydrogen energy at each stage of the three-stage integrated system. Accordingly, the three-stage system was found to possess rather low efficiency of light energy bioconversion even by taking into account the best results available in the literature. Therefore, it could be concluded that this scheme is unproductive for light energy bioconversion due to the numerous intermediate steps. Alternatively, direct light-dependent production of biofuels (ethanol, lipids, or hydrogen) by microalgae as elaborated by Sarsekeyeva et al. (2015) and Tsygankov and Abdullatypov (2015) might be more profitable.

\section{Acknowledgments}

This work was supported by the Russian Science Foundation No 15-1430007 .

\section{References}

[1] Asatiani, V., 1969. Enzymatic methods of analysis (Russ). Nauka, Moscow.

[2] Cheng, J., Xia, A.X., Liu, Y., Lin, R., Zhou, J., Cen, K., 2012. Combination of dark- and photo-fermentation to improve hydrogen production from Arthrospira platensis wet biomass with ammonium removal by zeolite. Int. J. Hydrogen Energy. 37, 13330-13337.

[3] Choi, S.P., Nguyen, M.T., Sim, S.J., 2010. Enzymatic pretreatment of Chlamydomonas reinhardtii biomass for ethanol production. Bioresour. Technol. 101, 5330-5336.
[4] Clayton, R.K., 1966. Spectroscopic analysis of bacteriochlorophylls in vitro and in vivo. Photochem. Photobiol. 5, 669-677.

[5] Efremenko, E.N., Nikolskaya, A.B., Lyagin, I.V., Senko, O.V., Makhlis, T.A., Stepanov, N.A. et al, 2012. Production of biofuels from pretreated microalgae biomass by anaerobic fermentation with immobilized Clostridium acetobutylicum cells. Bioresour. Technol. $114,342-348$.

[6] Erickson, L.E., Minkevich, I.G., Eroshin, V.K., 1978. Application of mass and energy balance regularities in fermentation. Biotechnol. Bioeng. 20, 1595-1621.

[7] Gfeller, R.P., Gibbs, M., 1984. Fermentative metabolism of Chlamydomonas reinhardtii. I: analysis of fermentative products from starch in dark and light. Plant. Physiol. 75, 212-218.

[8] González-Fernández, C., Sialve, B., Bernet, N., Steyer, J.P., 2012. Impact of microalgae characteristics on their conversion to biofuel. Part II: Focus on biomethane production. Biofuels, Bioprod. Biorefin. 6, 205-218

[9] Hanson, R., Phillips, G., 1984. Chemical composition of bacterial cell, in: Gerhardt, P. et al., (Eds.), Manual of Methods for General Bacteriology (Russian translation). Mir, Moscow, pp. 283-375.

[10] Harris, E.H., 1989. The Chlamydomonas Sourcebook: A comprehensive guide to biology and laboratory use. Academic Press, San Diego, pp. 780.

[11] Heiniger, E.K., Oda, Y., Samanta, S.K., Harwood, C.S., 2012. How posttranslational modification of nitrogenase is circumvented in Rhodopseudomonas palustris strains that produce hydrogen gas constitutively. Appl. Environ. Microbiol. 78, 1023-1032.

[12] Ike, A., Toda, N., Murakawa, T., Hirata, K., Miyamoto, K., 1998. Hydrogen photoproduction from starch in CO2-fixing microalga biomass by a halotolerant bacterial community, in: Zaborsky, O.R. (Ed.), Biohydrogen. Plenum Press, NY, pp. 311-318.

[13] Ike, A., Kawaguchi, H., Hirata, K., Miyamoto K., 2001. Hydrogen photoproduction from starch in algal biomass, in: Miyake, J., Matsunaga, T., San Pietro, A. (Eds.), Biohydrogen II: an approach to environmentally acceptable technology. Pergamon, Amsterdam, pp. 53-61.

[14] Jeon, B.H., Choi, J.A., Kim, H.C., Hwang, J.H., Abou-Shanab R.A.I,, Dempsy, B.A. et al, 2013. Ultrasonic disintegration of microalgal biomass and consequent improvement of bioaccessibility/bioavailability in microbial fermentation. Biotechnol. Biofuels. 6, 37-45.

[15] Kawaguchi, H., Hashimoto, K., Hirata, K., Miyamoto, K., 2001. H2 production from algal biomass by mixed culture of Rhodobium marinum A-501 and Lactobacillus amylovorus. J. Biosci. Bioeng. 91, 277-282

[16] Kim, M.S., Baek, J.S., Yun, Y.S., Sim, S.J., Park, S., Kim, S.-C. 2006. Hydrogen production from Chlamydomonas reinhardtii biomass using a two-step conversion process: Anaerobic conversion and photosynthetic fermentation. Int. J. Hydrogen Energy. 31, 812 316.

[17] Khusnutdinova, A.N., Hristova, A.P., Ovchenkova, E.P. Laurinavichene, T.V., Shastic, E.S., Liu, J. et al, 2012. New tolerant strains of purple nonsulfur bacteria for hydrogen production in a two-stage integrated system. Int. J. Hydrogen Energy. 37, 88208827

[18] Klass, D. L., 1998. Biomass for Renewable Energy, Fuels, and Chemicals. Academic Press, San Diego, CA.

[19] Lakaniemi, A.M., Hulatt, C.H., Thomas, D.N., Tuovinen, O.H., Jaakko A Puhakka J.A., 2011. Biogenic hydrogen and methane production from Chlorella vulgaris and Dunaliella tertiolecta biomass. Biotechnol. Biofuels. 4, 34-46.

[20] Lee, J.; Yoo, C.; Jun, S.; Ahn, C., Oh, H., 2010. Comparison of several methods for effective lipid extraction from microalgae. Bioresour. Technol., 101, 575-577.

[21] Liu, C.H., Chang, C.Y., Cheng, C.L., Lee, D.J., Chang, J.S., 2012 Fermentative hydrogen production by Clostridium butyricum CGS5 using carbohydrate-rich microalgal biomass as feedstock. Int. J. Hydrogen Energy. 37, 15458-15464. 
[22] Lyubimov, V.I., L'vov, N.P., Kirshteine, B.E., 1968. Modification of the microdiffusion method for ammonium determination. Prikl. Biochim. Microbiol. 4, 120-121.

[23] Miranda, J.R., Passarinho, P.C., Gouveia, L., 2012. Bioethanol production from Scenedesmus obliquus sugars: the influence of photobioreactors and culture conditions on biomass production. Appl. Microbiol. Biotechnol. 96, 555-564.

[24] Ormerod, J.G., Ormerod, S.K., Gest, H., 1961. Light-dependent utilization of organic compounds and photoproduction of hydrogen by photosynthetic bacteria. Arch. Biochem. Biophys. 64, 449-463.

[25] Park, J-I., Lee, J., Sim, S.J., Lee, J-H., 2009. Production of hydrogen from marine macro-algae biomass using anaerobic sewage sludge microflora. Biotechnol. Bioprocess Eng. 14, 307-315.

[26] Rizwan, M., Lee, J.H., Gani, R., 2015. Optimal design of microalgaebased biorefinery: Economics, opportunities and challenges. Appl. Energy. 150, 69-79.

[27] Ryu, M.H., Hull, N.C., Gomelsky, M., 2014. Metabolic engineering of Rhodobacter sphaeroides or improved hydrogen production. Int. J. Hydrogen Energy. 39, 6384-6390.

[28] Sarsekeyeva, F., Bolatkhan, K., Usserbaeva, Z.A., Bedbenov, V.S., Sinetova, M.A., Los, D.A., 2015. Cyanofuels: biofuels from cyanobacteria. Reality and perspectives. Photosynth. Res. 125, 329-340.

[29] Sheehan, J., Dunahay, T., Benemann, J., Roessler, P., 1998. A look back at $t$ e U.S. Department of Energy's aquatic species program: biodiesel from algae. National Renewable Energy Laboratory, Report NREL/TP580-24190.

[30] Sueoka, N., Chiang, K.S., Kates, J.R., 1967. Deoxyribonucleic acid replication in meiosis of Chlamydomonas reinhardtii. I. Isotopic transfer experiments with a strain producing eight zoospores. J. Mol. Biol. 25, 47-66.
[31] Tekucheva, D.N., Tsygankov, A.A., 2012. Coupled Biological Hydrogen_Producing Systems: A Review. Prikl. Biochim. Microbiol. 4, 357-375.

[32] Tsygankov, A.A., Abdullatypov, A., 2015. Hydrogen Metabolism in Microalgae, in: Allakhverdiev, S.I. (Ed.), Photosynthesis: New Approaches to the Molecular, Cellular, and Organismal Levels, Wiley-Scrivener, Beverly, pp. 133-162.

[33] Tsygankov, A.A., Laurinavichene, T.V., Gogotov, I.N., 1994 Laboratory scale photobioreactor. Biotechnol. Techn. 8, 575-578.

[34] Tsavkelova, E.A., Egorova, M.A., Petrova, E.V., Netrusov, A.I. 2012. Biogas production by microbial communities via decomposition of cellulose and food waste. Appl. Biochem. Microbio. 48(4), 377-384.

[35] Verma, N.M., Mehrotra, S., Shukla, A., Mishra, B.N., 2010 Prospective of biodiesel production utilizing microalgae as the cell factories: A comprehensive discussion. Afr. J. Biotechnol. 9, 14021411.

[36] Yang, Z., Guo, R., Xu, X., Fan, X., Li, X., 2011. Thermo-alkaline pretreatment of lipid-extracted microalgal biomass residues enhances hydrogen production. J. Chem. Technol. Biotechnol. 86 454-460.

[37] Yun, Y.M., Jung, K.W., Kim, D.H., Oh, Y.K., Cho, S.K., Shin, H.S., 2013. Optimization of dark fermentative H2 production from microalgal biomass by combined (acid + ultrasonic) pretreatment. Bioresour. Technol. 141, 220-226 